\title{
STARVING SPIRITS: FOOD CONSUMPTION AND GENDER VIOLENCE IN DIANA EVANS'S 26A AND HAN KANG'S THE VEGETARIAN ${ }^{1}$
}

\author{
Rosa Moreno Redondo ${ }^{2}$
}

\begin{abstract}
English title: Starving Spirits: Food Practices and Gender Violence in Diana Evans's 26a and Han Kang's The Vegetarian

Abstract: This article examines the conflicts experienced by the protagonists of $26 a$ (2005) by British-Nigerian Diana Evans and The Vegetarian (2007) by South Korean Han Kang, which are related to patriarchal violence and reflected in their changing dietary habits, ranging from vegetarianism to starvation. Their changes in food practices are interpreted from feminist, food studies, and ecocritical perspectives as stemming from their rebellion against patriarchal abuse and sharing important connections with the natural world, also a traditional object of male dominance and domestication, which are emphasised through frequent references to trees, flowers and fruit.
\end{abstract}

Key Words: Vegetarianism, starvation, female identity, patriarchal violence, ecocriticism, nature.

Título en Español: Espíritus hambrientos: prácticas alimentarias y violencia de género en $26 a$ de Diana Evans y The Vegetarian de Han Kang

Resumen: Este artículo examina los conflictos que experimentan las protagonistas de $26 a$ (2005) de la nigeriano-británica Diana Evans y The Vegetarian (2007) de la surcoreana Han Kang y que se relacionan con la violencia patriarcal y se reflejan en sus cambios de hábitos alimenticios, desde el vegetarianismo hasta la inanición. Sus cambios en las prácticas alimentarias se interpretan desde perspectivas feministas, de estudios de la comida y de la ecocrítica y surgen de su rebelión frente al abuso patriarcal, compartiendo conexiones importantes con el mundo natural, que también es un objeto tradicional de dominio masculino y domesticación, que se enfatizan a través de frecuentes referencias a árboles, flores y fruta.

Palabras clave: vegetarianismo, inanición, identidad femenina, violencia patriarcal, ecocrítica, naturaleza.

\section{Introduction}

Studies of food, consumption and gender often consider cooking a source of power for women due to its symbolic importance (Sceats 2003; Adolph 2009). However, more

\footnotetext{
${ }^{1}$ Fecha de recepción: 23/01/2019.

Fecha de aceptación: 28/11/2019.

${ }^{2}$ Profesora Asociada en el Departamento de Filología Española, Moderna y Clásica, Universitat de les Illes Balears, Mallorca. España. $\square$ rosa.moreno@uib.es.
} 
often than not, food practices uncover the patriarchal imposition which forces women to remain in the domestic sphere, and which essentially translates as their exclusion from the public domain. There is an extensive - though young - field of food studies that denotes the implications of food far beyond the physical act of feeding. The association of women and food is pervasive in literature from a multiplicity of perspectives, from women's physical capacity of nurturing others to the social expectations and conventions regarding female appetites. As sociologist Becky $\mathrm{W}$. Thompson states in her book $A$ Hunger so Wide and so Deep, "[i]t is no surprise that appetites and food take on metaphorical significance in a society in which women typically are responsible for food preparation and yet are taught to deny themselves ample appetites" (1994: 5). Food consumption and food practices have served as a vehicle for some contemporary female authors to criticize traditional gender roles. Moreover, Haber and Voski Avakian state that writing about food and cooking has also been a useful vehicle for women to express their creativity (2005: 2).

Narratives that present women's relationships with food often explore their resistance to conform to established gender expectations through their refusal to perform specific food practices. As literary critic Andrea Adolph states in Food and Femininity in Twentieth-Century British Women's Fiction (2009: 5), physical processes also reflect specific mental states, so those practices that affect the body also respond to needs that transcend the physical sphere. One of these practices is the refusal to eat meat, which has been associated with the rejection of masculinity by scholars like Carol Adams. In her article "Why Feminist-vegan Now?” (2010) Adams reviews her twenty-year-old theory that vindicates the association of eating meat with masculinity stating that it is culturally acknowledged that men socialise through meat. In The Sexual Politics of Meat (1990), 
Adams argues that Western popular culture identifies male socialisation with meat consumption, since fraternity is established through rituals that range from barbecue parties to hunting and fishing trips. Vegetables usually represent passivity, and vegetarianism has been associated with women and those who associate with them, and thus are regarded as less masculine. In this sense, the decision of abandoning meat consumption would respond to a resistance mechanism towards an imposition of masculinity (Adams 2010: 61-63). However, it would be a mistake to consider that this Western representation of masculinity is universal and applies equally to all societies regardless of culture, race or religion. In the same way, food practices are always rooted in the local culture and cannot be generalised to the experiences of women all over the world.

Refusing to eat meat usually implies the consideration towards others' wellbeing and - as Chavan puts it - "[vegetarianism] symbolizes the specific choice of a person to eat food." (2015: 156). Animal suffering is a global experience today; in the same way that women all around the world have undergone patriarchal oppression, animals have also been historically oppressed and still continue to be much so. Vegetarian and vegan characters have not been widely represented in literature in the last decades, and in many cases these representations have been negative and have emphasised the characters' malnourishment, misinformation, or even madness ${ }^{3}$. However, an increasing number of narratives portray female characters that are empowered by their choice to become vegetarian ${ }^{4}$. In the narratives explored in this article, vegetarianism partly responds to the

\footnotetext{
${ }^{3}$ Strict vegetarian and vegan characters are portrayed negatively in novels such as John Barth's Giles GoatBoy (1966) and Jonathan Franzen's The Corrections (2001). Vegans are also stereotyped in popular TV shows like How I Met your Mother (2005-2014) and The Millers (2013-2015).

${ }^{4}$ Some of the most relevant examples include Elizabeth Costello in J. M. Coetzee's novel of the same title (2003), Hazel Grace Lancaster in The Fault in our Stars (2012), and Mathilde in Lauren Groff's Fates and Furies (2015). There are also many popular TV shows and movies portraying female vegetarian characters,
} 
choice of avoiding violence towards others, but the subtext clearly responds to the aim of the protagonists to escape their memories of violence exerted on them by men. In this article I will focus on two contemporary novels of female authorship: Diana Evans's $26 a$ (2005) and Han Kang's The Vegetarian (2007). Evans is an award-winning novelist of British and Nigerian descent who writes in English and whose fiction focuses on the inner struggles of diasporic female characters, domesticity and family relationships being central to some of her novels. Han Kang is a South Korean author who writes in Korean and whose fiction often revolves around trauma and violence. The selected narratives have been studied under different literary perspectives in previous research: $26 a$ has been considered a diasporic novel that deals with hybrid identities and the struggle to belong, whereas The Vegetarian is often analysed from an ecocritical, and in particular ecofeminist perspective, considering the relationship between women and the environment as well as the relationship between women and meat consumption. In this article I will examine how both novels offer a similar construction of the theme of vegetarianism and consumption in relation to patriarchal oppression. First, the article will examine the relationship between women and food practices, considering the protagonists' personal background in relation to domesticity and social conventions. Then, I will consider the connection of trauma with the changes the characters experience in food practices as a possible mechanism to restore their balance, before finally moving on to explore how the trauma experienced by the protagonists is to some extent reduced by the efforts of other female characters in the novels.

although stereotypes are still quite notable. Examples include Lisa Simpson in The Simpsons (1989- ), Phoebe Buffay in Friends (1994-2004) and Elle Woods in Legally Blonde (2001). 


\section{Diet and gender in $26 a$ and The Vegetarian}

According to Sarah Sceats in Food, Consumption and the Body in Contemporary Women's Fiction, food is more symbolic than biological, not only in women's writing but as part of our lives; the things we eat and the people we eat with, how we identify with food and why, are important aspects of our everyday lives (2003: 1). At the same time, men and women identify with food in different ways, be it for reasons of patriarchal tradition or for modern cultural pressures related to the female body. Besides, women associate to food in the sense of being capable of feeding; they are traditionally those who nourish others, playing the role of carers and nurturers within the patriarchal family. Women characters in these two texts break with tradition through their dietary habits but they also express their conflict through food, which can be considered as served and eaten, but also as uneaten. Their separate stories contain similar motifs of nurturance and starvation, mostly presented in a negative light in relation to dominance and trauma.

Nancy Armstrong states that the only way that women have historically gained some power is exercising as housewives in the domestic sphere. The term relates to the historical association of women to the privacy of the household in opposition to the public sphere, which allowed for men to exert social power outside the family. However, Armstrong finds this power a paradox of modern culture because the importance of housekeeping surged as a political power but represented little achievement for women, as it empowered them just indoors while men had the world to explore (2001: 15). This sense of women remaining in the domestic sphere, where they are supposed to belong according to the patriarchal discourse, is an integral part of the protagonists' life stories 
in The Vegetarian and, in a different way, in 26a. I will argue that Yeong-hye's domesticity is imposed by cultural traditional values that do not allow her to grow as an individual, while Georgia's domesticity stems from her self-imposed stigma as a victim of sexual abuse and her conformity with social standards of beauty in order to regain her self-appreciation.

Yeong-hye is the protagonist in The Vegetarian. She plays the part of the dutiful young housewife in the context of 1980s South Korea. At that time, the political turmoil in the country ended in democracy and brought a rapid development to society. However, South Korea was in essence still controlled by the patriarchal powers of different governments and it remained strongly conservative (Kong, 1997; Chun, Doayl, Payne, Cho and Kim, 2006). It is fair to assume that Yeong-hye was raised in the basic Confucian imperative of respect and loyalty to the group, so all that is expected from her is that she behaves as a good wife and daughter. The novel reveals that Yeong-hye suffers physical abuse from her father as a child and, as the story unfolds and she rebels against the traditional values that have been set for her, she has to endure her father's physical violence again. Yeong-hye conforms to domesticity without complaint or questioning until she starts having repeated dreams of violence and blood that traumatise her and that she interprets as violence towards others. As a consequence, she decides to become a vegetarian so that she does not participate in harming others. However, instead of liberating her from violence, her decision of abandoning all animal products brings her physical abuse from her father, isolation from her family, and sexual abuse and rape from her husband, who wants to impose his authority in the face of her rebellion from established traditions. At the start of the novel Yeong-hye does not seem to have any eating disorder: her vegetarianism is a survival mechanism to cope with the abuse that 
she has suffered. However, later on she is diagnosed with anorexia because she stops eating altogether. By means of starvation Yeong-hye intends to change her nature and stop being human; in this way she perceives that her resistance to violence can only be achieved when she ceases to live.

Georgia is the protagonist of $26 a$ and she is a young woman who is not bound to the domestic sphere. Thompson states that considering women's bodily insecurities as products of an education that emphasises passivity does not contemplate other models of education, particularly for African-Americans "who are encouraged to be assertive, selfdirected, and active both within their families and publicly" (7). In fact, Georgia is an active young woman, second generation migrant of mixed heritage - her mother is Nigerian and her father is British - and a twin, which has a lot to say about her personality. The novel is set in 1980s London, at a time when Thatcher's conservative government made it difficult for migrants to earn their living. However, Georgia is raised comfortably in European fashion with her mother reminding her and the rest of her daughters often of Nigerian heritage. Georgia's breaking point is not a result of her upbringing: during a trip to Nigeria, the pre-adolescent Georgia suffers sexual abuse from an employee in her family home. This episode leaves her unresponsive and causes in her an irreparable trauma. From that point in Georgia's life her independence gives way to an introspection that canalises physically towards a domestication of her image. She bends to the pressure of social constraints regarding body image and she feels she needs to fit society standards in order to be herself. Georgia loves animals and stops eating certain foods because of her affection towards her pet hamster, but she has different reasons to eventually become a vegetarian. Her true aim is to cleanse herself physically as well as spiritually, since she feels dirty after her assault years earlier in Nigeria. The fact that she associates fruit and 
vegetables with rebirth is significant of the link between consuming the "flesh" of dead creatures and untimely, violent death. Georgia is trying to liberate herself from the violence imposed on others but also, and most importantly, on that exerted upon her body and mind. There are periods when she fasts to get thinner. However, her true ambition from this practice is occupying as little space as possible, as if trying to disappear. As happens with Yeong-hye, Georgia realises that her body cannot cure her mind, so she also decides to disappear completely and she dies of suicide ${ }^{5}$.

In the end, Yeong-hye and Georgia are dealing with eating problems that have nothing to do with their own self-image. We can find evidence in the Journal of Psychiatric and Mental Health Nursing that eating disorders, particularly anorexia, can be partly attributed to different cultural factors across even in the globalised world (Simpson 2002: 65). While anorexia has been commonly associated with white, middle class women in Western societies, it currently has an increasing incidence in black and Asian women; however, these women do not always present traits of fat-phobia. According to Simpson, cultural conflict can cause identity problems that trigger this psychiatric disorder (69) and this seems to be the case in both protagonists: Georgia's mixed heritage and her negative feelings towards Africa isolate her from her mother and sisters, and at the same time her identity as a twin is shattered from the momento that she considers herself as the dark, impure twin. In words of Samantha Reive Holland, "Africa, then, far from being a place of refuge, is at this point in the narrative a place to be distrusted, exposing the disjunctions between the girls' maternal ancestry and their present-day cultural experience" (Reive Holland 2017: 562). Yeong-hye also finds herself

\footnotetext{
5 Although traditionally phrased "committing suicide", mental health associations consider that it should not be criminalised, so it would be more accurate to describe suicide as an ailment that induces death.
} 
impure but only because she has been following her family's Confucian practices of obedience and authoritarianism; her upbringing has impeded her autonomy and growth.

The protagonists' food practices respond to acts of self-preservation that respond to the injustices that they have endured and that - according to Thompson - "will be cured only when the society cures itself of injustice" (1994: 21). Both protagonists suffer trauma and they deal with the consequences alone. The selves of the protagonists are divided between what they are and what they have been forced to become, but at the same time they are indivisible since they cannot get rid of their afflictions, and they are alienated from other people and from society in different ways because of this division. The real source of tribulation in the novels is the dependent status of women: both novels present women who have been scarred by male domination and whose last resort against injustice is solitary self-preservation that ends in death.

\section{Personal and social: Georgia's and Yeong-hye's experiences of gendered violence} and coping mechanisms

Georgia and Yeong-hye suffer because they cannot move on from their traumatic experiences and they cannot conform to the social and patriarchal definitions of normality. The ideal that both women pursue demands their demise because violence is part of being human, and only by ending their humanity they are able to avoid violence. Peter Iadicola and Anson Shupe argue in their book Violence, Inequality, and Human Freedom that it would be imposible to find a completely nonviolent culture, from a 
sociological standpoint: "In a sense all of us living in modern industrialized societies, regardless of our language or specific nationality, are inheritors of a violent tradition." (Iadicola and Shupe 2013: 63) The authors consider that humans are creators of symbols to which different negotiated and constructed meanings are attached (53). These symbols can have -and historically have had- the power to elicit violence.

Violence is thus traditionally normalised as in the case of slaughtering farm animals for human consumption. By becoming vegetarian, both characters are denying this normalisation. In the process of purifying their minds they are also cleansing their bodies and their perceptions of food reflect their inner struggle. Pérez-Fernández cites McDowell and Sharp (1997: 3) when they consider that the body is the first element that we use for communication with others and to explore and define our individuality (2013: 4). In this sense, the protagonists' thinning bodies become objects of resistance as well as vehicles to communicate their trauma.

According to Michael Allen Fox in "Vegetarianism and Planetary Health", "becoming vegetarian liberates us from the exploitation of animals, the domination of nature, and the oppression of one another, and frees us to discover ourselves in more positive, life-affirming ways" (2000: 183). As mentioned before, Adams pointed out that male dominance is evident in consumption, since meat eating is associated to masculinity while eating vegetables is associated to femininity. Animals are instrumentalised in the same way that women are also objectified in patriarchal societies, and the protagonists of the novels have suffered this objectification first hand. When both women suffer sexual assaults they are being deprived of their own individual physical space and their growth afterwards is marked by it as a consequence. 
From the moment Georgia is sexually assaulted, her perception of reality changes. Soon after being abused, on the plane home from Nigeria, the narrator describes Georgia's feelings: "Georgia had felt the colors and the rain, but she would not miss here. There was something lost. The nowness of things. It was not pretty". (2005: 87) From that moment she obsesses with light, colours and beauty, and she believes she has lost a light inside her. Her fingers become slippery as a possible metaphor of her trouble to handle reality. She actually feels better when she can escape reality in her dreams:

Georgia dangled on the edge of the house, on the edge of sleep, and dreamed in colors of Sekon, how the kitten felt that night, because in sleep she could remember. It felt as soft as a beginning, it felt simple, it felt like light in her hands. The best time, the best journeys are sleep, under a cover in the dark, and safe from the dark; we are free to roam back to our own first lights and find the ones we have lost, the unruined, the ones we dream of becoming again. (2005: 126)

Dreams are also a window to Yeong-hye's inner struggle. Unlike Georgia, her dreams are shadows that engulf her, and they are a painful reminder of her real struggle:

\begin{abstract}
Dreams of murder. Murderer or murdered ....hazy distinctions, boundaries wearing thin. Familiarity bleeds into strangeness, certainty becomes impossible. Only the violence is vivid enough to stick. A sound, the elasticity of the instant when the metal struck the victim's head...the shadow that crumpled and fell gleams cold in the darkness. They come to me now more times than I can count. Dreams overlaid with dreams, a palimpsest of horror. Violent acts perpetrated by night. A hazy feeling I can't pin down ... but remembered as blood-chillingly definite. Intolerable loathing, so long suppressed. Loathing I've always tried to mask with affection. But now the mask is coming off. That shuddering, sordid, gruesome, brutal feeling. Nothing else remains. Murderer or murdered, experience too vivid to not be real. Determined, disillusioned. Lukewarm, like slightly cooled blood. Everything starts to feel unfamiliar. As if I've come up to the back of something. Shut up behind a door without a handle. Perhaps I'm only now coming face-to-face with the thing that has always been here. It's dark. Everything is being snuffed out in the pitch-black darkness. (2015: 91, in italics in the original)
\end{abstract}

For Georgia, social stereotypes regarding body image also play an important part

in her food choices. Once she enters adolescence her body feels naturally awkward, but 
most importantly she feels that she is growing apart from her twin sister. The twins believe that they are two parts of a whole, and when Bessi follows her own way Georgia starts feeling incomplete. Georgia externalises her awareness of the social pressures associated to body image by starving herself in order to belong in a society that considers this normal. She combines her vegetarianism with a diet rooted in the principle of DIY happiness (Do-it-yourself happiness):

\begin{abstract}
Good health was happiness. The right foods, the right combination of vitamins and minerals and proteins sliding down into the body was a good, cleaning feeling of happiness. To wash it down each day with four pints (as advised in The Detox Bible) of fresh mountain water was a kind of minor DIY baptism, the restoration of the self to a state of purity. [ ] The aim was lightness, to glide, to slice through water, to take up very little space. At seven and a half stone the world was full of the possibility of yellow days. During three-day fruit and water detoxes she savoured the sensation of shrinking. (2005: 152)
\end{abstract}

Georgia is trying to disappear in a way that she just achieves by means of suicide, becoming ethereal, escaping physical existence. When she meets her boyfriend Toby Georgia realises she does not need to achieve happiness on her own, neither to follow a diet to "shrink". Nevertheless, she continues her ritual of starvation on her birthday, when Toby travels abroad. "Georgia had eaten no dinner before she left so that her stomach should be flat" (169) She does not overcome the darkness inside her and she decides to leave Toby to avoid engulfing him in her lightless instability. At that moment Georgia considers that lightness may only be achieved through death.

In Western society bodily oppression has traditionally been regarded as conventional and desirable due to the historical influence of Christianity. Moreover, women's clothes are designed to be more on show than those of men and women who are not thin are judged and criticised because they seem to abandon or refuse all desire to 
please men. And just like in Western culture, women in Asia - and particularly in South Korea - are under a lot of pressure regarding body image and appearance. Plastic surgery and the cosmetic industry are powerful influences in contemporary globalised societies. However, Yeong-hye does not present any signs of pressure from an aesthetic point of view. Her struggle is symmetrically opposite, since her wish is not to belong in human society any longer. She does not wear bras in public because she feels constricted, something that her husband knew before marrying her, but with time she does not even care if her blouse reveals her breasts in public which outrages her husband. Her experiences, shaped in her repetitive dream, make her reject her own nature altogether and she believes that she can purify herself if she abandons her humanity. When her brother-in-law sees Yeong-hye naked he is surprised that her body "said so much and yet was no more than itself" (248-249). She becomes only the essential part of herself, and he cannot even understand her but he considers "she could not be called a "person"” (2015: 250). Yeong-hye is testing the boundaries between the human world and the vegetable world by taking her body to the limit.

Narrative techniques play an important role in the representation of both Yeong-hie and Georgia. In $26 a$ there is an omniscient narrator entering the consciousness of different characters including Georgia but she only has her own voice after she is dead, narrating her own experience when she transcends the physical boundaries of her body. The Vegetarian describes Yeong-hye through the perceptions of different characters; the only fragment giving access to her voice is her dream, Yeong-hie's recurrent nightmare where she is haunted by visions of blood and slaughtered animals. In Yeong-hye's narrative we hear three voices: the voice of the oppressor - her husband - the voice of the one who wants to take advantage of her - her brother-in-law - and the voice of her sister In-hye 
who is judgemental at first but eventually realises they are not so different. Only In-hye's voice remains until the end of the narrative. However, Yeong-hye, the victim of violence, has no voice in the same way that animals cannot express with voices the violence exerted against them.

Both Georgia and Yeong-hye use their bodies as spaces of change in their process of self-identification. However, this is not only an individual process but something that affects their permanence in the collective sphere. Eating is a social activity. Food practices are cultural practices that unite people but also have the power to keep them apart. In both narratives the idea of collectivity and belonging is pointed out from different perspectives. Although both cultural backgrounds revolve powerfully around traditional culinary practices, in The Vegetarian this collectivity is broken because of lack of family acceptance from Yeong-hye's family. Yeong-hye is isolated because she refuses to maintain the food practices that encourage her individual sense of belonging inside her family group. At a deeper level she is also rebelling against the traditional gendered role of conformity; instead, she tries to find inclusion in nature. In 26a, Georgia is in a private world that she only shares with her twin sister. This private space allows the twins to explore their personalities until the abuse makes Georgia consider that they are not synchronised anymore and thus she isolates herself from her tiny community of two, trying to recover some light from the beauty she sees in nature; she feels as if she does not belong anywhere any more. The family's lack of communication makes them oblivious to the fact that Georgia is suffering and only her death brings unity to the family, who are finally capable of communicating with each other.

It could be argued that Georgia's lack of communication is the onset of her eating disorder and eventual mental breakdown: not being able to share her trauma does not give 
her the chance to heal. She finds herself caught between her past identity and her inability to move on and fulfill herself as an individual. She cannot respond to trauma other than disappearing. Yeong-hye's struggle is perhaps even sadder because there are witnesses to the abusive episodes of gendered violence she endures as a child. She needs to live with the fact that they were tolerated. When Yeong-hye becomes a vegetarian her change in behaviour is considered the onset of madness, particularly by her father and husband. Her father tries to force-feed her, and her husband forces her to have sexual intercourse several times. All of them are trying to force their realities on Yeong-hye and her rejection to abuse is evidenced in her emaciation. The doctors in the mental hospital are not certain why Yeong-hye refuses to eat. None of the medicines they give her has any effect, which may indicate that she does not have any mental disorder. Yeong-hye has meditated her decision to abandon all physical life in order to overcome trauma.

Research in psychology shows that the unconscious mind can repress a traumatic event; in doing so, the brain is helping the traumatised person to cope with it. However, the consequences of the trauma can be the outcome of that suppression. Both Georgia and Yeong-hye suffer violence early in their lives, and may have experienced the symptoms of their repressed personal traumas. Their similar endings portray their individual attitudes towards violence and also conform a collective experience in gendered violence. Both protagonists give their lives because they cannot cope with the reality of belonging to a violence-ridden human world. At the same time, the social experiences of the protagonists are essentially different; Zeynep Ekin Bal and Muge Caroline Dikencik consider that, sociologically, anorexia is a symbolic opposition as well as a biologic symptom (Bal and Dikencik 2013: 493). The authors argue that dying of suicide can be partly attributed to the "weaknesses of social ties", but anorexia considered as a form of 
suicide can be seen as a reaction to an over-exposure to society's over-protection and discipline. Both Georgia and Yeong-hye suffer from anorexia, but while it seems that Georgia reacts against gender abuse and consciously disciplines herself in an attempt to gain control of her identity through gaining control of her body, Yeong-hie exerts her power by giving up control altogether, allowing herself to resist social impositions through her passivity.

\section{Female support in the novels: mothers, sisters and "mother earth"}

In the protagonists' attempt to improve their situation there are other women who try to help them in differing ways. These are mainly their mothers and their sisters. Sceats mentions that we connect food with love through the figure of the mother: nurturer and socialiser (2000: 11). Motherhood is an empowering role that at the same time binds women to domesticity. A mother can feed the body without nurturing it, without giving it psychological fulfillment. This does not mean that nurturers are evil, but maybe they

are insecure or inadequate. The ideal of motherhood is an imposition that cannot be fulfilled in these narratives as I shall discuss now, and this leaves the protagonists even more exposed to male oppression.

We never learn much about Yeong-hye's mother: she does not even have a name. Kang's intention may have been to portray her lack of individuality and independence. Indeed Yeong-hye's mother is the archetype of domesticity and gender submission related to tradition, and she is said to care less for her second daughter Yeong-hye than 
for her other children. It could be argued that her nurturing love may be culturally conditioned. In-hye is her first born and she has a good connection to all her groups: family and work. She is a successful businesswoman as well as a wife and mother. Then there is also Yeong-ho, her son, who traditionally will inherit the family properties and continue their blood line with the family surname. Yeong-hye is caught in the middle, with an innocent disposition that makes her less "valuable" in the eyes of her family. Yeong-hye's mother reacts towards her vegetarianism by worrying about her individualism and rebellion from the established roles in marriage. She is worried about Yeong-hye's health too, and she tries to give her food directly in the mouth at the family reunion, as if her daughter was an infant. Yeong-hye's direct refusal creates a horrifying scene in which her father tries to force feed her while her siblings immobilise her. According to Sneja Gunew, the father's act can be regarded as a form of rape, since it is "an assault that breaches [Yeon-hye's] bodily integrity." (Gunew 2016: 12) He even exerts more violence on her daughter, hitting her and making her react by self-harming Neither Yeong-hye's mother nor the rest of the family help her in this situation and, once they bring her to hospital, Yeon-hye's mother only fears for her health; she is prepared to lie to her so that her daughter eats meat without telling her, again having no respect for her daughter's decisions and invalidating her individual choices. Yeong-hye's mother disobeys her husband's wishes by visiting her daughter in hospital, which shows how worried she is and her true care for her. However, when the family realises that Yeonghye is a lost cause they banish her from the family circle. Only In-hye remains by her sister to take care of her; from that point in the narrative, In-hye's family circle is reduced to her son and her sister. 
Pérez-Fernández considers that Georgia’s parents - Ida and Aubrey - are "lost, uprooted and incomplete beings themselves, [they] are unable to function as stable referents for Georgia and Bessi's childhood identities" (2013: 10). While Aubrey has trouble relating to his daughters' experiences, Ida has control over the domestic sphere and transmits her cultural background to her daughters, teaching them about her Nigerian roots while they grow up in a European country. Ida escapes Nigeria at a time of political turmoil because she does not want to surrender to patriarchal impositions. She escapes an arranged marriage and eventually marries an Englishman and moves to his country. Once there she realises that her husband Aubrey and his mother Judith make her miss her own mother Nhe-nhe and she talks to her spirit every day, even though she is not dead. Her struggle to fit in the new country makes her long for her past and memories, so she is tied to that feeling of displacement and does not pay the same attention to her present family life. She has four daughters that she loves equally, but it is also culturally that she believes that her twin daughters Bessi and Georgia take care of each other and live in a world of their own that she cannot reach, and thus she is more focused on her first daughter Bel, the one who is closest to her Nigerian roots, and her youngest Kemi, whose age makes her more vulnerable.

Aubrey and his mother try to "colonise" Ida by trying to make her change her cooking, and they buy her English cookbooks: At one point her mother-in-law insists on giving her English cookery lessons to make sure that Aubrey "was being looked after properly" (52). Ida's cooking is the most important part of her identity; she does not intend to change her traditions because she is already struggling with her feelings of unbelonging in England. Ida protects her heritage the same way that she protects her daughters, standing by them when there is conflict even when she needs to challenge 
Aubrey to do so. However, the lack of communication with her husband takes its toll on Ida, whose introspection grows and separates her from her family. In $26 a$, like in The Vegetarian we find examples of loving food giving that comes from motherly love, but the mothers' personal situation makes it difficult - if not impossible - to connect with the daughters' personal struggles. Still, sibling love arises as a source of altruistic care and responsibility.

Sister relationships in the novels happen in a more modern generation, and they bring hope to the lives of the protagonists. It is through the sisters' understanding of their own identity that they start to empathise with the protagonists' experiences. Being twins, the relationship between Bessi and Georgia is very special. They support each other in every aspect. In the novel, fruit becomes a symbol of their togetherness:

Bessi took a nectarine from the bag but did not eat it right away. First, she concentrated on what she had to remember: the moment before. The moment before - when it was possible to sit with her back against Georgia's back — was in the nectarine. It was soft and sweet and it was ready to be eaten. She brought the fruit to her mouth. She took a bite. The juice of the nectarine slid down her chin and she caught it with a finger. She concentrated on chewing and tasting. It was a perfect nectarine, but there was something not right. Bessi could not taste the sunset. If Georgia was sitting next to her as a whole other person, she would be able to eat the sunset. "You made the world taste better," she said out loud. (2005: 267-268)

When Georgia is sexually assaulted during her stay in Nigeria, she never manages to recover. She chooses not to tell Bessi because she does not want to corrupt what she considers the purity of her twin. Georgia believes that she has become the dark twin, the one who must endure all kinds of evil. She wants to protect Bessi but in the process she breaks the perfect understanding they share. This separation makes Bessi more independent but Georgia more fragile. As they become adults, Georgia's decline into isolation and depression continues. This novel is filled with magical realism and after 
Georgia's death we see how the twins regain togetherness when Georgia's spirit enters Bessi's body for three months and tells her all about death. However, it is only in death that Georgia can connect with her sister again.

The same images of fruit appear in The Vegetarian. When Yeong-hye is hospitalised in a terminal state of starvation, her sister In-hye tries to feed her fruit invoking her childhood, and thus the time of innocence that Yeong-hye so desperately needs to recover. Even when Yeong-hye insists on the fact that she does not need to eat any more, In-hye tries to recall the good memories from Yeong-hye's past through food. She brings her peaches and watermelon and she presses them to her sister's lips without success, feeling powerless and angry at the fact that her sister has chosen to die:

\begin{abstract}
"It's a peach, Yeong-hye. A tinned Hwangdo peach. You like them, remember? You used to insist on buying them even when fresh peaches were in season, just like a child." She carves off a piece of the ripe, yielding fruit with a fork and brings it up to Yeong-hye's nose. "Smell that...don't you want to try a bit?" The next container is filled with watermelon, cut up into conveniently sized cubes. "Don't you remember, when you were young, every time I cut a watermelon in half you would come and smell it? With some of them, when we cut them up they gave off this wonderful sweet smell that spread through the whole house." Yeong-hye remains entirely motionless. In-hye gently rubs a piece of melon against her sister's lips. She tries to use two of her fingers to part Yeong-hye's lips, but her mouth is shut tight. "Yeong-hye," In-hye says. Her voice is low. "Answer me, Yeong-hye." She shakes her sister by her stiff shoulders, and resists the temptation to force her mouth open. She wants to yell right into her sister's ear: What are you doing? Are you listening to me? Do you want to die? Do you really want to die? Dazed, she examines the hot anger that is boiling up inside her like spume (2015: 159).
\end{abstract}

It is only at the end that the sisters get close. After much consideration In-hye eventually understands that she needs to protect her little sister from the coercive treatment of the nurses and doctors at the mental hospital who try to force-feed her. It is only after Yeong-hye has suffered that In-hye realises that her sister has endured pain all 
her life, first to the hands of their father and now from everyone around her, and she cannot be indifferent any more.

In Western thought, women have been traditionally associated with nature and men with culture. The concept of Mother Earth is based on women's reproductive function, both being recognised as part of a life-giving whole. However, even if being closer to nature can be considered positive from an ecocritical perspective, many feminists refuse to accept this approach to nature grounded in biological sex, taking into consideration that gender is culturally constructed and, therefore, a gender hierarchy exists within patriarchal societies. The basic ecofeminist perception is that the gap between nature and culture enables patriarchal oppression; Val Plumwood refers to this problem in these terms:

The western mapping of a gender hierarchy on to the nature/culture distinction has been a major culprit in the destruction of the biosphere. But if we think that the fact of being female guarantees that we are automatically provided with an ecological consciousness and can do no wrong to nature or to one another, we are going to be badly disappointed. (1994: 10)

Nevertheless, Plumwood considers that the disengagement of women from nature favours the assumption that nature is inferior. Instead, she rejects the dualism nature/culture since women as well as men are part of both; the different relationship of men and women with nature does not have to be expressed in terms of biology or essentialism, but instead can respond to the different social and historical positions of women and men (2003: 36).

In the novels, the uprooting of the women protagonists from nature can be seen as a manifestation of the patriarchal forces whose impulse is to exert dominance upon those 
considered inferior. Nature is connected to Georgia's life to the point that it is crucial and belongs to her inner self. The narrative reflects the unity between Georgia and her twin sister in the same way that it reflects Georgia's relationship with the vegetable world in the novel. The use of metaphors that liken humanity and nature shows that for them there is no difference. Georgia inherits from her mother the idea of trees as friends. Her mother Ida talks to the tree in the village in Nigeria when she escapes an arranged marriage and eventually the country. The tree becomes a symbol of reassurance for her. At the same time, the evergreen tree in the family's garden in London becomes a symbol of togetherness and belonging for Georgia, it reassures her that her connection to her twin sister Bessi is meant to last forever, like the leaves of the tree. When Georgia starts to decay after being sexually abused, nature around her mimics her deterioration. The human and the natural worlds get separated after the act of male aggression, and Georgia cannot unite them again. Then the images of nature become less soothing: the apple trees, which were the twins' responsibility, fade away. Georgia goes back to the evergreen tree but her sister has forgotten about it and thus it does not offer Georgia any comfort.

Flowers are important in Georgia's development too. As a child, she believes that they are more important than food. Beauty is essential for Georgia, and when she grows up this is evidenced in her efforts to be attractive and conform to beauty standards. Georgia's teenage dream is to become a florist, but when she grows up she cannot cope with colours, and thus she cannot cope with flowers. It seems that she cannot cope with beauty any more. As another example of magical realism, we learn from Georgia's spirit when she dies that only after leaving her physical body - and her human condition - she has connected again with nature, and that she is able to paint all the flowers she wants in all the colours she wants. 
In The Vegetarian nature is absent from Yeong-hye's life. There is an irreconcilable strangeness between humanity and nature throughout the novel and this can be interpreted as a clear message that human nature is corrupted and that is why it is absent from any connections with the vegetable world. This is a misanthropic notion that understands human nature - or at least human culture - as violent and the natural world as redeeming. Just like Georgia, Yeong-hye is a victim of male dominance and violence and she tries to escape their imprint forever. She tells her sister In-hye that all the trees of the world are like brothers and sisters. They represent the purest innocence that she wants to achieve, far from human violence. It is something that has always been denied to her because she has always endured the cruelty of men. In her process towards escaping her human nature, Yeong-hye tries to get rid of all human constraints. She stops eating meat, so that she does not need to harm any other living beings. Then she tries to live from the rain and the sun, as a plant would. She exposes her naked body to the rays of the sun because she does not feel nudity to be embarrassing any more. She has freed that concept from any moral considerations because she does not feel a part of human society any more. Her silence in the novel follows an extensive tradition, since there are many allusions in literature and classical mythology involving trees, rape and silence, but more importantly it parallels the silence of the non-human, of those who have been denied a voice. In this sense, Yeong-hye is already outside the human world, since she is a possession for the men in her family and an object of observation for the rest of society.

Flowers are also present in the novel and important for Yeong-hye. Her brother-inlaw paints flowers on Yeong-hye's body as a way of artistic sublimation but also as a way of possession. We see his male gaze when he wants to go a step further and have his own body painted too and then have sex with Yeong-hye while they are covered in painted 
flowers. Yeong-hye embraces body painting because she believes that flowers, though artificial, are going to appease her violent nightmares. She is aroused by the vegetable world and she believes it will help her in her communion with nature. It may also relate to the Buddhist practice derived from Thaoism by which bodies are protected from evil by painting sacred sutras on them. However, she soon understands that nothing that she does is enough to stop the nightmares and get rid of violence. The flower-sutras may protect her from external evil, but they cannot erase the human nature that she feels to be the source of violence.

\section{Conclusion}

In conclusion, however different these two novels may seem, both share certain characteristics that bring them close to each other. Both narratives depict female conflict provoked by gendered violence, which is dealt with through changes in food practices. Vegetarianism is understood in both novels as a means to achieve physical as well as spiritual cleansing, and regarded as a way to avoid being part of the cycle of violence that is inherent to the human condition. At first it is the means for the protagonists to regain inner peace by not inflicting harm on others. However, later there is also fasting in the novels, which is perceived as an attempt to get rid of the physical constraints that tie the protagonists to their personal lack of fulfillment, although they do so in different ways and for different periods of time. Their final demise projects their inability to balance their identities, which have been altered by episodes of male abuse. Despite their different 
literary backgrounds, both novels portray gender conflict and female rebellion as central themes, independently of geography and culture.

The different portrayals of nature and the different relationships that the protagonists have with it outline the same implication of male dominance as the main source of disruption between the natural and the human worlds. Georgia and Yeong-hye participate in nature in different ways but none of them succeeds in connecting with nature in a way that can save them. While the father figures in the novels are either nonresponsive or plainly abusive, the mother figures cannot connect with the daughters' experiences since the mothers themselves are not free to escape the gender hierarchy. Sorority in the novels does not help the protagonists escape death either. However, but the protagonists' rebellion and death at least serve for their sisters to understand them and brings new hope by creating a collective awareness of women's struggle.

\section{References}

Adams, Carol J. 2010 (1990). The Sexual Politics of Meat. A Feminist-Vegetarian Critical Theory. New York and London: Continuum.

Adams, Carol J. 2010. "Why Feminist Vegan Now" Feminism \& Psychology. 20, 3: 302317.

Adolph, Andrea. 2009. Food and Femininity in Twentieth-Century British Women's Fiction. Surrey and Burlington: Ashgate.

Armstrong, Nancy. 1987. Desire and Domestic Fiction: A Political History of the Novel. Oxford and New York: Oxford University Press. 
Bal, Zeynep Ekin and Dikencik, Muge Caroline. 2013. "Anorexia Nervosa as a Modern Disease: A Comparative Study of Different Disciplines" Procedia - Social and Behavioral Sciences. 82: 492-495.

Cho, Sung-Il, Chun, Heeran, Kim, Il-Ho, Doyal, Lesley and Payne, Sarah. 2006. "Understanding Women, Health, and Social Change: The Case of South Korea". International Journal of Health Services. 36, 3: 575-592. http://citeseerx.ist.psu.edu/viewdoc/download?doi=10.1.1.872.4419\&rep=rep1\&t ype=pdf [15 Jan. 2019]

Chavan, Shama. 2015. “A Study on Vegetarianism” Research Horizons. 156, 5: 156-159.

Evans, Diana. 2005. 26a. London: Chatto \& Windus.

Fox, Michael Allen. 2000. "Vegetarianism and Planetary Health." Ethics and the Environment. 5, 2: 163-174.

Haber, Barbara and Voski Avakian, Arlene (eds.). 2005. From Betty Crocker to Feminist Food Studies: Critical Perspectives on Women and Food. Amherst and Boston: University of Massachusetts Press.

Iadicola, Peter and Shupe, Anson. 2013. Violence, Inequality and Human Freedom. Plymouth: Rowman \& Littlefield Publishers, Inc.

Kang, Han. 2015. The Vegetarian. London and New York: Crown Publishing. Translated from the Korean by Deborah Smith. Original title 채식주의자 Ch'aesikjuuija (2007).

Kong, Mee-Hae. 2015. "Rethinking Women's Status and Liberation in Korea” United Nations Public Administration Network. http://unpan1.un.org/intradoc/groups/public/documents/APCITY/UNPAN005847. pdf [15 Jan. 2019)

Pérez-Fernández, Irene. 2013. "Embodying 'twoness in oneness' in Diana Evans' 26a" Journal of Postcolonial Writing. 49, 3: 291-302.

Plumwood, Val. 2003 (1993). Feminism and the Mastery of Nature. London and New York: Routledge.

Reive Holland, Samantha. 2017. ““Home had a way of shifting”: Cosmopolitan belonging in Diana Evans's 26 ${ }^{a}$ ' Journal of Postcolonial Writing. 53, 5: 555-566.

Sceats, Sarah. 2003 (2000). Food, Consumption and the Body in Contemporary Women's Fiction. Cambridge: Cambridge University Press.

Simpson, K. J. 2002. "Anorexia Nervosa and Culture" Journal of Psychiatric and Mental Health Nursing. 9: 65-71.

Sneja, Gunew. 2016. "Excess of Affect: In Translation” Hecate. 42, 2: 7-22. 
Thompson, Becky W. 1994. A Hunger so Wide and so Deep. A Multiracial Look of Women's Eating Problems. Minneapolis and London: University of Minnesota Press. 